\title{
Haematological Responses in Rohu Labeo rohita (Hamilton) after Infecting with Aeromonas hydrophila in Biofloc Systems
}

\author{
P. Anand Prasad ${ }^{1}$, H. Shivanandamuthy ${ }^{2}$, D. Ravindra Kumar Reddy ${ }^{1}$, \\ M. Ganapathy Naik ${ }^{2}$, Gangadhara Gowda ${ }^{5}$, K. Mansingh Naik ${ }^{2}$, \\ A. Chandra Sekhara Rao ${ }^{1}$ and T.V. Ramana ${ }^{1}$ \\ ${ }^{1}$ College of Fishery Science Muthukur, Nellore, Andhra Pradesh India \\ ${ }^{2}$ College of Fisheries Mangalore, Karnataka, India \\ *Corresponding author
}

\section{A B S T R A C T}

Keywords

Haematological responses

Labeo rohita

Aeromonas

hydrophila

Article Info

Accepted:

10 November 2018

Available Online:

10 December 2018
Rohu fishes grown with biofloc for 120 days have been examined for the histopathological changes occurred in the intestine and kidney after infecting with Aeromonas hydrohila with $0.5 \mathrm{ml}, 1.0 \mathrm{ml}$ and $1.5 \mathrm{ml}$ where $1.5 \times 10^{5}$ bacteria per $\mathrm{ml}$. In the present study haematological alterations were documented after Aeromonas hydrophila infected rohu (Labeo rohita) fingerlings, fed with probiotic supplemented diets with rice bran and ground nut oil cake in biofloc with added ammonium chloride to reduce $\mathrm{NH}_{3}$. Blood based parameters like $\mathrm{RBC}, \mathrm{Hb}, \mathrm{WBC}$, Neutrophils, lymphocytes, monocytes, MCV, MCH, MCHC, PCV etc. were analyzed which revealed a significant alteration after infecting with Aeromonas hydrohila.

\section{Introduction}

Aquaculture intensification is one of the prime requirements to cope with the present demand for fish protein. Increase in productivity per unit space is performed by increasing the rearing density of fishes. Health management and biosecurity are major challenges in production intensification due to limited control over pathogens (Kautsky et al., 2000).

Aquaculture is an important economic activity supplying high quality animal protein to greater number of people worldwide, and the global growth of the industry remains relatively strong with an average annual growth rate of $8.6 \%$ (FAO, 2014). However, modern farming techniques and recent trend of intensification of aquaculture operation has brought in new challenges that threaten the health of farmed species, leading to growth reduction and immunosuppression, all culminating into massive financial loss and reduced profit margins for farmers (Smith et al., 2003). Biofloc technology (BFT) based farming system has proved to be a limited 
water exchange, biosecure system which can ensure sustainable feeding management and production intensification. The benefits include the uptake of ammonium by the microbial community by maintaining a high $\mathrm{C} / \mathrm{N}$ ratio (Avnimelech et al., 1994) and improve health management and bio security through zero-water exchange and possible probiotics effect (Crab et al., 2010).

Several pathogenic organisms such as bacteria, fungi and viruses have been reported to be principal limiting factors to the growth of aquaculture industry. The most common and frequently encountered bacterial pathogen in tropical climates is A. hydrophila, which causes severe damage to carp production (Karunasagar et al., 1991). It is a deadly pathogen causing stress-related diseases in fish with the common symptoms of ulceration, exophthalmia and abdominal distension (Amin et al., 1985).

\section{Materials and Methods}

Rohu fish (30+30 numbers) cultured in biofloc for 120 days were collected and kept in separate aquaria tanks (6) 10 fishes in each aquarium for control and treatments. After acclimatizing in aquaria they have been infected with Aeromonas hydrophila with the concentrations of $0.5 \mathrm{ml}, 1 \mathrm{ml}$ and $1.5 \mathrm{ml}$ and the bacterial count in each $\mathrm{ml}$ was $1.5 \times 10^{5}$ cells per ml of culture media.

\section{Blood collection}

At the end of the experiment, one fish collected from each treatment, thus a total three fishes have been used for blood collection. Blood was collected from the caudal vein by using No.24 gauge syringe, previously rinsed with 10\% EDTA solution. Blood collected was transferred immediately to a heparinized tube and shaken gently to prevent haemolysis of blood cells. $50 \mu$ of collected blood sample from each treatment and control was immediately analyzed for Red Blood Cell (RBC) count, White Blood Cell (WBC) count, platelet count, hemoglobin content (Hb), hematocrit value, Mean Corpuscular Volume (MCV), Mean Corpuscular Hemoglobin $(\mathrm{MCH})$ and Mean Corpuscular Hemoglobin Concentration (MCHC) (Rusia and Sood, 1992). The hematological parameters were analysed by using the hematology analyzer, (Pentagan Medical Instrument, PHA-23PLUS, China)

\section{Results and Discussion}

\section{Haematology}

Results found after haematology are given in detail in Table 1 . Hb levels in the infected fishes in the present study differed from 9.8, 8.6, $6.3 \mathrm{~g} / \mathrm{dL}$ in $0.5,1.0$ and $1.5 \mathrm{ml}$ doses respectively and in control it was $10.1 \mathrm{~g} / \mathrm{dL}$. Tivary and Pandey (2014) got 9.21 in healthy rohu, post infection 6.73, and chronic infection $153.6 \mathrm{~g} / \mathrm{de}$. RBC was $2.11,1.71$, and $1.49 \mathrm{mil} / \mathrm{cubmm}$ in control, post infection and chronic infection was observed and in the present experiment 2.38, 1.82, 1.54, and 1.47 mil/cubmm. WBC 31.4, 19.82, and 16.89 $10^{3} / \mu 1$ present study shows $1.295,1.345,1.39$ and $1.508 \mathrm{lakh} / \mathrm{cubmm}$. Lymphocytes 22.6, 8.87 and $6.1110^{3} / \mu 1$ this experiment shows 96, 98, 102, and 108 alternatively in control, $0.5 \mathrm{ml}, 1.0 \mathrm{ml}$ and $1.5 \mathrm{ml}$ doses. Monocytes $1.62,2.83,3.3410^{3} / \mu 1$ in the present study 2 , 2.1, 2.2, 2.4 alternatively. MCV 185.6, 169.3 and 153.6 in their result and present study shows 141, 111, 118 and 124 fl. MCHC23.56, 24.12 and 21.64 has been resulted in their experiment and in the present study 30.1, 42.2, 39.2 and $34.6 \mathrm{gm} / \mathrm{L}$ was observed. The WBC count indicates a lenkopenia with lymphopenia, mild neutrophils and monocytosis. Haematological changes were more pronounced in fish with extensive skin ulcers. 
Table.1 Dosages of Aeromonas hydrophila and blood cells comparison with control

\begin{tabular}{|c|c|c|c|c|}
\hline & $\mathbf{0 . 5} \mathbf{~ m l}$ & $\mathbf{1 . 0} \mathbf{~ m l}$ & $\mathbf{1 . 5} \mathbf{~ m l}$ & Control \\
\hline Hb g/dL & $9.8 \pm 0.2$ & $8.6 \pm 0.18$ & $6.3 \pm 1.2$ & $10.1 \pm 0.6$ \\
\hline RBC mil/cumm & $1.82 \pm 0.6$ & $1.54 \pm 0.3$ & $1.47 \pm 0.2$ & $2.38 \pm 0.4$ \\
\hline WBC /cumm & $1,34,500 \pm 1000$ & $1,39,000 \pm 800$ & $1,50,800 \pm 900$ & $1,29,500 \pm 700$ \\
\hline \multicolumn{4}{|c|}{ Differential Count in \% } \\
\hline Neutrophils & $0.9 \pm 0.1$ & $0.8 \pm 0.1$ & $0.5 \pm 0.01$ & $1 \pm 0.2$ \\
\hline Lymphocytes & $98 \pm 6$ & $102 \pm 8$ & $106 \pm 4$ & $96 \pm 5$ \\
\hline Eosiniphils & $0.4 \pm 0.1$ & $0.2 \pm .02$ & 0 & $1 \pm 0.2$ \\
\hline Monocytes & $2.1 \pm 0.1$ & $2.2 \pm 0.1$ & $2.4 \pm 0.2$ & $2 \pm 0.3$ \\
\hline Basophils & $0.2 \pm 0.01$ & $0.1 \pm 0.01$ & 0 & 0 \\
\hline Platelet Count cumm & $53,500 \pm 300$ & $78,200 \pm 600$ & $1,02,000 \pm 400$ & $3,27,000 \pm 600$ \\
\hline Hematocrit/Pcaked & $10.3 \pm 0.9$ & $14.8 \pm 2.4$ & $18.2 \pm 3.6$ & $33.6 \pm 6.4$ \\
Cell Volume Vol\% & & & & \\
\hline MCV fl & $111 \pm 10$ & $118 \pm 18$ & $124 \pm 14$ & $141 \pm 18$ \\
\hline MCH pg & $44.2 \pm 9$ & $43.6 \pm 6$ & $43.0 \pm 7$ & $42.4 \pm 4$ \\
\hline MCHC gm/L & $42.2 \pm 6$ & $39.2 \pm 5$ & $34.6 \pm 8$ & $30.1 \pm 4$ \\
\hline RDW \% & $11.3 \pm 2.1$ & $16.7 \pm 2.6$ & $20.2 \pm 3.1$ & $28.0 \pm 2.8$ \\
\hline MPV & $5.4 \pm 1.2$ & $6.2 \pm 0.9$ & $6.7 \pm 1.8$ & $6.9 \pm 0.8$ \\
\hline
\end{tabular}

Leukopenia was lymphocyte as predominant circulating leukocyte (Latimer et al., 2003). The exact mechanism of lymphopenia is not clearly known but it may be redistribution of lymphocytes induced by corticosteroids as occur in mammals.

The mild neutrophilia and monocytosis probably occurs in response to tissue demand for these cells can also be observed in histological sections. Leukopenia with lymphopenia, nutrophilia and occasional monocytosis is frequently observed in viral and other gram negative bacterial diseases of fish (Noga, 2000). Hemoglobin and RBC increased and nutrophils have been decreased in the all treatments compared to control and WBC and lymphocytes, monocytes count has been increased when compared with control and the same has been shown in the results of Dharmakar (2017).

\section{References}

Amin N.E., Abdallah I.S., Elallawy T. and
Ahmed S.M. (1985) Motile Aeromonas septicaemia among Tilapia nilotica (Sarotherodon niloticus) in upper Egypt. Fish Pathology 20, 93-97.

Avnimelech, Y., Kochva, M., Diab, S., 1994. Development of controlled intensive aquaculture systems with a limited water exchange and adjusted carbon to nitrogen ratio. Isr. J. Aquacult. Bamidgeh. 46, 119-131.

Crab, R., Lambert, A., Defoirdt, T., 2010. The application of bioflocs technology to protect brine shrimp, Artemia franciscana from pathogenic Vibrio harveyi. J. Appl. Microbiol. 5, 16431649.

Dharmakar, Padala ( 2017) "Effect of dietary peppermint (Mentha piperita) on growth, survival, disease resistance and hematology of indian major carp, rohu (Labeo rohita)" pp:26

FAO (2014). The State of World Fisheries and Aquaculture. Opportunities and Challenges, pp. 18-21. Food and Agriculture Organization of the United 
Nations, Rome, Italy.

Karunasagar, I., Rosalind, G.M. and Karunasagar, I. (1991). Immunological response of the Indian major carps to Aeromonas hydrophila vaccine. Journal of Fish Diseases. 14, 413-417.

Latimer, K.S. and Frasses, K.S. (2003) Leukocytes (In: Duncan \& Frasses's veterinary laboratory medicine: Clinical Pathology) Ed. Latimer K.S, Mahaffey, E.A., Prassikw, $4^{\text {th }}$ Ed. Pp:46-79, IOWA Noga, E.T., (2000) Fish leukocyte responses ( In: Schalm's veterinary hematology, Ed. Feldman B.F., Zinki, J.A., Jani, N.C., $5^{\text {th }}$ Ed.) pp:433-439. Lipponeott Williams and Wilkins, Baltimore, M.D.
Rusia, V., Sood, S.K., Routine haematological tests, in: Kanai, L. Mukerjee I. (Eds.), Medical Laboratory Technology Vol. 1, Tata McGraw Hill, New Delhi, 1992, pp. 252-258.

Smith, V.J., Brown, J.H. and Hauton, C. (2003). Immunostimulation in crustaceans: does it really protect against infection. Fish Shellfish Immunology. 15, 71-90.

Tiwari, C.B., and Vijay Shankar Pandey, (2014). Studies of histology in Labeo rohita infected with cutaneous columnaris disease. Rec.zool.Surv.India: 114(Part-1): 151157.

\section{How to cite this article:}

Anand Prasad, P., H. Shivanandamuthy, D. Ravindra Kumar Reddy, M. Ganapathy Naik, Gangadhara Gowda, K. Mansingh Naik, A. Chandra Sekhara Rao and T.V. Ramana. 2018. Haematological Responses in Rohu Labeo rohita (Hamilton) after Infecting with Aeromonas hydrophila in Biofloc Systems. Int.J.Curr.Microbiol.App.Sci. 7(12): 1150-1153.

doi: https://doi.org/10.20546/ijcmas.2018.712.141 